\title{
Therapeutic applications based on cannabinoids action
}

\author{
Ricardo Plancarte-Sánchez, ${ }^{1}$ Armando Mansilla-Olivares, ${ }^{2 *}$ Víctor Alfonso De los Reyes-Pacheco and \\ Fernando Meneses-González ${ }^{3}$ \\ ${ }^{1}$ Secretaría de Salud, Instituto Nacional de Cancerología; ${ }^{2}$ Faculty of Medicine, Universidad Nacional Autónoma de México; ${ }^{3}$ Academia Nacional \\ de Medicina. Ciudad de México, Mexico
}

\begin{abstract}
The interest on cannabinoids became evident between the 1940 and 1950 decades. Although the active substance of the plant was not known, a series of compounds with cannabinomimetic activity were synthesized, which were investigated in animals and clinically. The most widely tested was $\Delta 6 \square, 100-T H C$ hexyl. $\Delta 6 \alpha, 10 \alpha-T H C$ dimethylheptyl (DMHP) antiepileptic effects were studied in several children, with positive results being obtained in some cases. DMHP differs from sinhexyl in that its side chain is DMHP instead of $n$-hexyl. The first cannabinoid isolated from Cannabis sativa was cannabinol, although its structure was correctly characterized several years later. Cannabidiol was isolated some years later and was subsequently characterized by Mechoulam and Shvo. In 2013, the National Academy of Medicine and the Faculty of Medicine of the National Autonomous University of Mexico, through the Seminar of Studies on Entirety, decided to carry out a systematic review on a subject that is both complex and controversial: the relationship between marijuana and health. In recent years, studies have been conducted with cannabis in several diseases: controlled clinical trials on spasticity in multiple sclerosis and spinal cord injury, chronic, essentially neuropathic, pain, movement disorders (Gilles de Latourette, dystonia, levodopa dyskinesia), asthma and glaucoma, as well as non-controlled clinical trials on Alzheimer's disease, neuroprotection, intractable hiccups, epilepsy, alcohol and opioid dependence and inflammatory processes.
\end{abstract}

KEY WORDS: Cannabinoids. Tetrahydrocannabinol. Cannabis sativa. Chronic pain. Neuropathic pain.

\section{Introduction}

On June 19, 2017, in the Official Gazette of the Federation, reforms and additions were published regarding the use of tetrahydrocannabinol (THC), as well as isomers and stereochemical variants, pharmacological derivatives of Cannabis sativa, indica and Americana (hereinafter marijuana). The controversy that has developed in the political and academic sphere, as well as the concerns that have arisen in the population in relation to known and poorly-known effects of the use of marijuana, have allowed the writing of this work. Herein, a review is made of reported therapeutic applications with the use of cannabis derivatives, emphasizing on the role cannabinoids play, and thereby contributing to the understanding of the probable therapeutic use of this plant and its derivatives. $^{1}$

\section{The cannabis plant}

The cannabis plant is a term that groups the genus Cannabis, which comprises the Cannabis Sativa, Cannabis Indica, Cannabis Americana and Cannabis ruderalis plants. In general, cannabis is known as marijuana and has at least a bit more than 100 different synonyms; Table 1 presents some.

Worldwide prevalence of marijuana consumption is estimated to be $3.8 \%$, which means there are approximately 183.3 million users. One of the central problems is the consumption of marijuana by individuals under
Correspondence:

*Armando Mansilla-Olivares

E-mail: armandoautor1@gmail.com
Date of reception: 14-12-2018

Date of acceptance: 17-12-2018

DOI: 10.24875/GMM.18004928
Gac Med Mex. 2019;155:283-294

Contents available at PubMed www.gacetamedicademexico.com 
Table 1. Marijuana synonyms

\begin{tabular}{|c|c|c|c|c|c|c|}
\hline Aceite (oil) & Alfalfa & Chora & Coffe & Chabela & Chíchara & Chipiturca \\
\hline Churro (joint) & $\begin{array}{l}\text { Churro de la buena } \\
\text { (joint of the good stuff) }\end{array}$ & $\begin{array}{l}\text { De la verde } \\
\text { (of the green stuff) }\end{array}$ & $\begin{array}{l}\text { Diosa verde } \\
\text { (green } \\
\text { goddess) }\end{array}$ & Doña diablo & $\begin{array}{l}\text { Dama de la } \\
\text { ardiente cabellera } \\
\text { (lady with the } \\
\text { burning hair) }\end{array}$ & $\begin{array}{l}\text { Flor de Juana } \\
\text { (Juana flower) }\end{array}$ \\
\hline Goma (gum) & Grifa & Grilla & Güera (blond) & $\begin{array}{l}\text { Hierba } \\
\text { (grass) }\end{array}$ & Join & Juana \\
\hline Juanita & $\begin{array}{l}\text { Mala hierba } \\
\text { (bad grass) }\end{array}$ & María & Mari & Mariana & Mary Poppins & Mois \\
\hline Mora & Mota & Motivosa & $\begin{array}{l}\text { Motocicleta } \\
\text { (motorcycle) }\end{array}$ & Mole & Mostaza (mustard) & Nena (baby) \\
\hline $\begin{array}{l}\text { Nalga de ángel } \\
\text { (angel's buttock) }\end{array}$ & Orégano (oregan) & $\begin{array}{l}\text { Orégano chino } \\
\text { (Chinese oregan) }\end{array}$ & $\begin{array}{l}\text { Oro verde } \\
\text { (green gold) }\end{array}$ & Pasto (grass) & $\begin{array}{l}\text { Petate (palm } \\
\text { straw) }\end{array}$ & Pachola \\
\hline $\begin{array}{l}\text { Pepita verde } \\
\text { (green nugget) }\end{array}$ & Porro (joint) & $\begin{array}{l}\text { Soñadora } \\
\text { (dreamer) }\end{array}$ & Tónico (tonic) & $\begin{array}{l}\text { Tostada } \\
\text { (toast) }\end{array}$ & $\begin{array}{l}\text { Tronadora } \\
\text { (thundering) }\end{array}$ & $\begin{array}{l}\text { Trueno verde } \\
\text { (green thunder) }\end{array}$ \\
\hline Verdolaga (purslane) & $\begin{array}{l}\text { Yerbabuena } \\
\text { (spearmint) }\end{array}$ & $\begin{array}{l}\text { Yerba de } \\
\text { oro (golden grass) }\end{array}$ & $\begin{array}{l}\text { Yerba del diablo } \\
\text { (grass of the } \\
\text { devil) }\end{array}$ & $\begin{array}{l}\text { Yerba santa } \\
\text { (holy grass) }\end{array}$ & Yesca (tinder) & Zacate (grass) \\
\hline
\end{tabular}

García-Robles J. Antología del vicio. Aventuras y desventuras de la mariguana en México. Mexico: Laberinto; 2016.

Table 2. Legal status of the use and consumption of marijuana in countries of the European Union

\begin{tabular}{|c|c|c|c|}
\hline Country & Legal situation & Regulatory law & Amount of drug allowed \\
\hline Germany & $\begin{array}{l}\text { Use and possession for personal } \\
\text { consumption }\end{array}$ & BtMG Law & $6 \mathrm{~g}$ of marijuana and up to $0.5 \mathrm{~g}$ of heroin and cocaine. \\
\hline Spain & $\begin{array}{l}\text { Use and possession for personal } \\
\text { consumption }\end{array}$ & Organic law 1/1992 & $\begin{array}{l}\text { Marijuana: } 25 \mathrm{~g} \text { of resin and } 200 \mathrm{~g} \text { of grass; } 7.5 \mathrm{~g} \text { of } \\
\text { cocaine, } 2.4 \mathrm{~g} \text { ecstasy and } 3 \mathrm{~g} \text { of heroin. }\end{array}$ \\
\hline Portugal & Legalization and decriminalization & 30/2000 law & $\begin{array}{l}25 \mathrm{~g} \text { of marijuana, } 5 \mathrm{~g} \text { of cannabis resin, } 2 \mathrm{~g} \text { of cocaine, } \\
1 \mathrm{~g} \text { of heroin, } 1 \mathrm{~g} \text { of ecstasy. }\end{array}$ \\
\hline Finland & $\begin{array}{l}\text { Use and possession for personal } \\
\text { consumption }\end{array}$ & Law ss. 3, 27 & $\begin{array}{l}1 \text { plant or } 3 \mathrm{~g} \text { of cannabis or cannabis resin for personal } \\
\text { consumption. }\end{array}$ \\
\hline Italy & $\begin{array}{l}\text { Use and possession for personal } \\
\text { consumption }\end{array}$ & Fini law & $500 \mathrm{mg}$ marijuana, $250 \mathrm{mg}$ of heroin, $750 \mathrm{mg}$ of cocaine. \\
\hline Belgium & Administrative sanctions, misdemeanor & Col. 2/2005 & $\begin{array}{l}1 \text { plant or } 3 \mathrm{~g} \text { of cannabis or resin for personal } \\
\text { consumption. }\end{array}$ \\
\hline $\begin{array}{l}\text { Czech } \\
\text { Republic }\end{array}$ & Administrative sanctions, misdemeanor & $\begin{array}{l}\text { Offense act 30/1/jllaw } \\
40 / 2009\end{array}$ & $\begin{array}{l}15 \mathrm{~g} \text { of marijuana, } 1.5 \mathrm{~g} \text { of heroin, } 1 \mathrm{~g} \text { of cocaine, } 2 \mathrm{~g} \text { of } \\
\text { methamphetamine, } 5 \text { ecstasy pills. }\end{array}$ \\
\hline $\begin{array}{l}\text { The } \\
\text { Netherlands }\end{array}$ & Legalization and decriminalization & Opiumwet Opium Law & No amount limit for self-consumption. \\
\hline
\end{tabular}

18 years of age. In 23 member countries, the Organization for Economic Cooperation and Development has estimated that $9.3 \%$ of 15 -year-old men used marijuana in the previous 30 days, as well as $6.3 \%$ of women of the same age. ${ }^{2,3}$ In Mexico, the prevalence of marijuana use once in life in the population of 12 to 65 years of age is $8.6 \%, 2.1 \%$ in the previous year (1.8 million are estimated in that age group) and $1.2 \%$ in the previous month. In the population aged 12 to $17,5.3 \%$ reported having consumed marijuana. ${ }^{4}$ In a sample of secondary and high school students in Mexico, a prevalence has been reported of marijuana use sometime of $10.6 \%$, $12.9 \%$ by males and $8.4 \%$ by females. ${ }^{5}$

Cannabis, specifically the sativa species, is an herbaceous plant that grows spontaneously in tropical and subtropical regions and contains between 400 and 537 chemical components and nearly 100 cannabinoids. $^{6,7}$ It is difficult to pinpoint the moment any 
Cannabis sativa preparation started being used. Its origin is located in Central Asia and its use has been described in the Chinese pharmacopoeia as part of traditional medicine. It was an Iranian physician, Sir William B. O'Shaughnessy, a Calcutta resident, who for the first time scientifically assessed the therapeutic value of the plant; he published his findings in the early $19^{\text {th }}$ century. 8,9

The use of its compounds throughout history has shown variants, as it occurs with the healing properties associated with its consumption, within the existing medical knowledge framework of every era. The effects it produces, mainly on the brain, were associated with religious practices. Currently, its consumption is widely spread all over the world, without having any relationship with religious aspects as in the past. Its main use, due its psychotropic effects, is ludic, although therapeutic properties are associated. ${ }^{10-13}$

The actions that have been developed for marijuana legal consumption have been diverse and include its growth, marketing and use. Several legal changes have been made in relation with cannabis personal possession and consumption, such as possession and consumption legalization and decriminalization. Table 2 shows the various provisions that have been adopted in some countries of the European Union. ${ }^{14}$

In Mexico, on June 19, 2017, in the Official Gazette of the Federation, reforms and additions were published with regard to the use of THC, as well as isomers, stereochemical variants and pharmacological derivatives of Cannabis sativa, indica and Americana (marijuana). Article 235 Bis of the General Statute of Health states that "[.] the Ministry of Health shall design and implement public policies that regulate the medicinal use of Cannabis sativa, indica and Americana, or marijuana, pharmacological derivatives, including THC, its isomers and stereochemical variants, as well as to regulate research and domestic production thereof". 15

\section{Cannabinoids}

In the study and research of cannabinoids and their pharmacological properties, at least three stages are recognized:

- Research on Cannabis, encompassing from its description in the Chinese pharmacopoeia, circa year 200, until the decade of 1940, where cannabidol synthesis by Adams stands out (1940).

- The second stage, which focuses on cannabinoid research and goes from the Adams report until
1993, the year in which Munroe reports the finding of the clone $\mathrm{CB}_{2}$ receptor.

- The last stage, whose emphasis is on research on endocannabinoids, where the report of enzymes that biosynthesize endocannabinoids and the launch onto the market of some synthetic cannabinoids such as Sative ${ }^{\circledR}$ stand out.

The first Cannabis sativa isolated cannabinoid was cannabis resin cannabinol (Wood, Spivey and Easterfield, 1899); however, its structure was characterized several years later (Adams, Baker and Wearn, 1940). Cannabidiol was isolated a few years later (Adams, Hunt and Clar, 1940) and was subsequently characterized by Mechoulam and Shvo. ${ }^{16}$

In the 1940s and 1950s, research around cannabinoids increased, so that compounds with cannabinomimetic activity were synthesized, among which $\Delta 6 \alpha$, $10 \alpha$-THC hexyl (pirhexyl or sinhexyl) stands out. Subsequently this compound was documented to differ from THC only in a double bond between $6 \alpha$ and $10 \alpha$ and in that it has an $\mathrm{N}$-hexyl in the side chain, instead of $\mathrm{N}$-pentyl. ${ }^{17}$

In this context of the development of research on cannabis derivatives, it has been established that this plant has psychotropic and therapeutic effects mediated by cannabinoids. Out of these, three main types stand out:

- Phytocannabinoids, directly extracted from Cannabis sativa and Cannabis Indica, which possess cannabinoids with psychotropic effect such as delta-9-tetrahydrocannabinol ( $\triangle 9$-THC) and others without psychotropic effects but with some potential therapeutic effect.

- Endocannabinoids, which are synthesized in the brain or peripheral tissues and act on cannabinoid receptors.

- Synthetic cannabinoids, synthesized in laboratories with a similar structure to that of phytocannabinoids and endocannabinoids and that act through similar biological mechanisms. ${ }^{18}$

The identified cannabinoids have been classified in 10 subclasses according to their chemical structure: ${ }^{19}$

1. Cannabigerol.

2. Cannabichromene.

3. Cannabidiol.

4. $\triangle 9$-THC.

5. $\triangle 8$-THC.

6. Cannabicyclol (CBL).

7. Cannabielsoin (CBE).

8. Cannabinol and cannabinodiol (CBND).

9. Cannabitriol (CBT).

10. Miscellaneous. 


\section{Endocannabinoid system}

To understand the physiological and pharmacokinetic effects of any of the three types of cannabinoids, the cannabinoid system or endogenous cannabinoid system has to be understood, which is a complex endogenous signaling system constituted by four elements:

- CB1 and CB2 cannabinoid receptors coupled to G-proteins.

- Endogenous endocannabinoids that target these and possibly other receptors.

- Enzymes that catalyze endocannabinoid biosynthesis and metabolism.

- Specific mechanisms involved in accumulation of specific endocannabinoid cells.

The most widely investigated are cannabinoid receptors CB1 and CB2, located in the neuronal cell membrane, especially at presynaptic terminals. ${ }^{20}$

Currently, a broad definition of the endogenous cannabinoid system is being used, and using the term "endocannabinoid-like mediators" is preferred. ${ }^{21,22}$

Cannabinoid receptors CB1 and CB2 are differentiated by the way they transmit the signal and by their distribution in different tissues. Cannabinoid receptors activation results in adenylatocyclase inhibition, which prevents the conversion of ATP to cyclic AMP; on the other hand, their interaction with some ionic channels' activity has been demonstrated. Both CB1 and CB2 belong to the broad family of protein G-coupled receptors. ${ }^{21} \mathrm{CB} 1$ receptor activation results in effects on memory processing, mood, sleep, motor regulation, appetite and pain sensation, while CB2 activation does not produce said effects. CB1s are mainly found in the cortex, spinal cord and peripheral nervous system neurons, although they are also present in certain peripheral organs and tissues, such as endocrine glands, salivary glands, leukocytes, spleen, the heart and in certain areas of the reproductive, urinary and gastrointestinal systems. ${ }^{22}$

There are $\mathrm{CB} 1$ receptors in both central and peripheral nerve terminals, which inhibit the release of some neurotransmitters. Thus, CB1 receptors activation protects the nervous system against over-activation or over-inhibition elicited by neurotransmitters. CB1 receptors are found in the regions of the brain responsible for movement (basal ganglia, cerebellum), memory processing (hippocampus, cerebral cortex) and pain modulation (certain parts of the spinal cord, periaqueductal grey), while their presence in the brainstem is low, which may explain the absence of adverse effects at this level as a result from cannabis use. The brainstem, among other functions, controls breathing and circulation. CB2 receptors are mainly found in immune cells, including leukocytes, the spleen and tonsils. ${ }^{23}$

One of $C B$ receptors' functions in the immune system is modulation of the release of cytokines, which are responsible for inflammation and immune system regulation. Since the compounds that selectively activate CB2 receptors (CB2 receptor agonists) do not cause psychological effects, they are increasingly becoming the target of investigation of cannabinoids therapeutic applications as analgesics, anti-inflammatory and antineoplastic agents. In fact, there is evidence of the existence of cannabinoid sub-receptors, such as GPR 55, and the orphan receptors coupled to a G-protein. Other receptors may be only functionally related to the well-known cannabinoid receptors, with a similar structure to that of $\mathrm{CB} 1$ and CB2. ${ }^{22}$

After cannabinoid receptors were identified, their endogenous ligands, known as endocannabinoids, were discovered. In the brain, they act as neuromodulators. Endocannabinoids so far identified include anandamide ( $\mathrm{N}$-arachidonoyl-ethanolamide), 2-arachidonoyl-glycerol, 2-arachidonyl-glyceryl ether (noladin ether), O-arachidonoyl-ethanolamine (virodhamine) and $\mathrm{N}$-arachidonoyl-dopamine. ${ }^{23}$

Anandamide and $\mathrm{N}$-arachidonoyl-dopamine not bind to cannabinoid receptors, but also share the ability of capsaicin, a component of hot peppers, to activate vanilloid receptors. Endocannabioid signaling is characterized because these molecules are not synthesized or stored in nervous cells, but are generated from their precursors and released on demand. ${ }^{24}$

\section{Affinity for cannabinoid receptors}

Cannabinoids show different degree of affinity for $\mathrm{CB} 1$ and $\mathrm{CB} 2$ receptors. Synthetic cannabinoids have been developed that act as agonists or selective antagonists for either receptor. $\triangle 9$-THC has about the same affinity for both $\mathrm{CB} 1$ and $\mathrm{CB} 2$ receptors, while anandamide has very low selectivity for $\mathrm{CB} 1$; $\mathrm{THC}$ and anandamide effectiveness is lower in CB2 than in CB1 receptors. ${ }^{25}$ Although most physiological actions of cannabinoids (behavioral, memory, euphoria, immobility, analgesia, hypothermia, sedation effects) are attributed to their action on $\mathrm{CB} 1$ and $\mathrm{CB} 2$ receptors, pharmacological studies and in CB1 or CB2-knockout 
Table 3. Comparison of the first three jurisdictions in the world that legally regulate the use of marijuana: Colorado, Washington and Uruguay

\begin{tabular}{|c|c|c|c|}
\hline Item & Colorado & Washington & Uruguay \\
\hline Level of law & $\begin{array}{l}\text { State constitution, laws and } \\
\text { regulations }\end{array}$ & State law and regulations. & National Law and Executive Order \\
\hline $\begin{array}{l}\text { Regulatory } \\
\text { agency }\end{array}$ & Colorado Department of Revenue & Washingston State Liquor Board (LCB) & $\begin{array}{l}\text { Institute for the Regulation and } \\
\text { Control Cannabis (a public, } \\
\text { non-state entity) }\end{array}$ \\
\hline $\begin{array}{l}\text { Definition of } \\
\text { marijuana }\end{array}$ & $\begin{array}{l}\text { All parts of plant, seed, resin } \\
\text { extracted from any part of the plant, } \\
\text { and every compound, manufacture, } \\
\text { salt, derivative, mixture or preparation } \\
\text { of the plant, its seeds or its resin, } \\
\text { including marijuana concentrate, } \\
\text { which is cultivated, manufactured, } \\
\text { distributed or sold by a certified } \\
\text { or licensed retail marijuana } \\
\text { establishment. Does not include } \\
\text { industrial hemp or the weight of any } \\
\text { another ingredient combined with } \\
\text { marijuana to prepare topical or oral } \\
\text { administrations, food, drink or other } \\
\text { product. }\end{array}$ & $\begin{array}{l}\text { All parts of the plant with a THC } \\
\text { concentration greater than } 0.3 \% \text { on a } \\
\text { dry weight basis; the seeds thereof; the } \\
\text { resin extracted from any part of the plant } \\
\text { and every compound, manufacture, salt, } \\
\text { derivative, mixture or preparation of the } \\
\text { plant, its seeds or resin. }\end{array}$ & $\begin{array}{l}\text { Flowering tops with or without the } \\
\text { fruit of the female cannabis plant, } \\
\text { except the seeds and leaves } \\
\text { separated from the stem, including } \\
\text { the oils, extracts, preparations } \\
\text { for potential pharmaceutical use, } \\
\text { syrups and the like, to which the } \\
\text { natural tetrahydrocannabinol } \\
\text { content is equal to or more than } \\
1 \% \text { of its volume. }\end{array}$ \\
\hline $\begin{array}{l}\text { Quantity for } \\
\text { personal } \\
\text { possession }\end{array}$ & 1 ounce $(28.5 \mathrm{~g})$. & 1 ounce $(28.5 \mathrm{~g})$. & $40 \mathrm{~g}$ (1.4 ounces). \\
\hline $\begin{array}{l}\text { Domestic } \\
\text { cultivation } \\
\text { for personal } \\
\text { consumption }\end{array}$ & $\begin{array}{l}6 \text { plants, with } 3 \text { in flower and } \\
\text { possession of the marijuana produced } \\
\text { by plants at the } \\
\text { cultivation site }\end{array}$ & None & $\begin{array}{l}\text { Up to } 6 \text { flowering plants per } \\
\text { household with a maximum } \\
\text { production quantity of } 480 \mathrm{~g} \text { per } \\
\text { year. }\end{array}$ \\
\hline Minimum age & 21 & 21 & 18 \\
\hline $\begin{array}{l}\text { Retail } \\
\text { transaction } \\
\text { limitation }\end{array}$ & $\begin{array}{l}1 \text { ounce }(28.5 \mathrm{~g}) \text { of marijuana or its } \\
\text { equivalent in retail marijuana product } \\
\text { to Colorado residents. Up to a } \\
\text { quarter of that amount for out of state } \\
\text { residents. }\end{array}$ & $\begin{array}{l}1 \text { ounce ( } 28.5 \mathrm{~g} \text { ) usable marijuana, } 16 \\
\text { ounces of marijuana-infused product } \\
\text { in solid form, } 7 \mathrm{~g} \text { of marijuana-infused } \\
\text { extract for inhalation and } 72 \text { ounces of } \\
\text { marijuana-infused product in liquid form }\end{array}$ & $\begin{array}{l}40 \mathrm{~g} \text { ( } 1.4 \text { ounces }) \text { of marijuana per } \\
\text { month. }\end{array}$ \\
\hline $\begin{array}{l}\text { Residency } \\
\text { requirements }\end{array}$ & $\begin{array}{l}\text { For its purchase, see above. For } \\
\text { obtaining a license, a minimum of } \\
2 \text { years residence is required. }\end{array}$ & $\begin{array}{l}\text { None for purchasing. For obtaining a } \\
\text { license, a minimum of } 3 \text { months residence } \\
\text { is required. }\end{array}$ & $\begin{array}{l}\text { For purchasing, domestic } \\
\text { cultivation and membership } \\
\text { in cannabis clubs, Uruguayan } \\
\text { legal or naturalized citizenship or } \\
\text { permanent Uruguayan residency } \\
\text { is required. None specified for } \\
\text { licenses. }\end{array}$ \\
\hline $\begin{array}{l}\text { User registry } \\
\text { for non-medical } \\
\text { purposes }\end{array}$ & None. & None. & $\begin{array}{l}\text { Registration with the Institute } \\
\text { of Regulation and Control of } \\
\text { Cannabis is required for purchase } \\
\text { in pharmacies, domestic } \\
\text { cultivation or membership in } \\
\text { cannabis clubs. }\end{array}$ \\
\hline $\begin{array}{l}\text { Consumption in } \\
\text { public spaces }\end{array}$ & $\begin{array}{l}\text { No "open and public" consumption. } \\
\text { Smoke free zones included. Drug } \\
\text { petty offense of USD \$ } 100 \text { and fine } \\
24 \text { hours community service. }\end{array}$ & $\begin{array}{l}\text { Unlawful to use marijuana in view of general } \\
\text { public. USD } \$ 50 \text { civil fine. }\end{array}$ & $\begin{array}{l}\text { Consumption in the public } \\
\text { spaces is with the exception } \\
\text { of closed public spaces, } \\
\text { workplaces, public transportation, } \\
\text { educational centers, health } \\
\text { establishments or sports } \\
\text { institutions }\end{array}$ \\
\hline
\end{tabular}


Gaceta Médica de México. 2019;155

Table 3. Comparison of the first three jurisdictions in the world that legally regulate the use of marijuana: Colorado, Washington and Uruguay (Continued)

\begin{tabular}{|c|c|c|}
\hline Item & Colorado & Washington \\
\hline $\begin{array}{l}\text { Driving under } \\
\text { the influence of } \\
\text { marijuana }\end{array}$ & $\begin{array}{l}\text { New THC } 5 \mathrm{ng} / \mathrm{mL} \text { blood per se } \\
\text { driving under the influence of } \\
\text { drugs (DUID) creates a rebuttable } \\
\text { presumption. }\end{array}$ & New THC 5 ng/mL blood per se DUID. \\
\hline $\begin{array}{l}\text { Outdoor } \\
\text { commercial } \\
\text { cultivation }\end{array}$ & Allowed & Allowed \\
\hline $\begin{array}{l}\text { Commercial } \\
\text { cultivation }\end{array}$ & $\begin{array}{l}\text { Licensed marijuana cultivation } \\
\text { facilities. }\end{array}$ & Licensed marijuana products. \\
\hline $\begin{array}{l}\text { Commercial } \\
\text { retail outlets. }\end{array}$ & Licensed retail marijuana store. & Licensed dealer. \\
\hline $\begin{array}{l}\text { Market } \\
\text { integration }\end{array}$ & Allowed. & Prohibited. \\
\hline Taxes & $\begin{array}{l}15 \% \text { excise tax from cultivation to } \\
\text { processing or retail. } 10 \% \text { excise } \\
\text { tax on sale, in addition to any } \\
\text { existing local or state sales tax. }\end{array}$ & $\begin{array}{l}25 \% \text { excise tax at each stage of sales (producer } \\
\text { to processor to retailer to customer). }\end{array}$ \\
\hline $\begin{array}{l}\text { Production and } \\
\text { distribution } \\
\text { limits. }\end{array}$ & $\begin{array}{l}\text { As of September } 2014 \text {, } \\
\text { establishments must grow at } \\
\text { least } 70 \% \text { of the marijuana they } \\
\text { sell and sell no more than } 30 \% \text { of } \\
\text { what they grow to other outlets. }\end{array}$ & $\begin{array}{l}\text { Producers, processors and retailers are limited } \\
\text { to } 3 \text { licenses, no more allowed to hold more } \\
\text { than } 33 \% \text { of the allowed licenses in any county } \\
\text { or city. Maximum cultivation is } 2 \text { million square } \\
\text { feet statewide. Maximum limit of retail licenses } \\
\text { issued by LCB is based on population. Currently } \\
\text { at } 334 \text {. }\end{array}$ \\
\hline
\end{tabular}

\section{Uruguay}

Zero tolerance.

Allowed for those registered for domestic cultivation, cannabis clubs or authorized producers.

Licensed marijuana producers.

Licensed pharmacies.

Allowed by the law, but not implemented.

Taxed by Value Added Tax under a VAT suspension regime, allowing the producers to deduct VAT from their purchases and preventing the transfer of the tax to the final price. There is no tax on agricultural assets.

Not specified in the law or regulations. The regulatory body will define the authorized production quantity.

Packaging and labeling regulations

Product warning labels of health

effects.

Child-resistant packaging

Required for final sale of marijuana retail product.

Advertising

Permitted but restricted to avoid reaching minors under 21 for retail establishments. Signage permitted at place of business in compliance with local ordinances.

Advertising Not misleading or safety claims warnings can be made.

Internet sale
Prohibited.
Yes: quantity, serving size, ingredients, potency.

Yes.

Required for marijuana-infused products meant to be eaten, swallowed or inhaled.

Restricted to no more than a sign for retailers at place of business. Prohibited for producers and processors.

Detailed and required.

Prohibited
Yes: specifications, safety conditions and maximum quantity $10 \mathrm{~g}$.

Yes.

To be established during the call for applications for production licenses.

Not permitted.

No advertising allowed, either directly or indirectly.

Prohibited. 
Table 3. Comparison of the first three jurisdictions in the world that legally regulate the use of marijuana: Colorado, Washington and Uruguay (Continued)

\begin{tabular}{|l|l|l|}
\hline Item & Colorado & Washington \\
\hline Security systems & Required and detailed. & Required and de \\
\hline & & \\
\hline Cannabis clubs & Not permitted. & Not permitted. \\
\hline
\end{tabular}

Medical

marijuana

Taxes and fee distribution laws.
Yes, continuing in existence with new laws and are tax exempt. Prorated fees when converting medical retailer to non-medical.

First \$ 40 million dollars to Public School Capital Construction Assistance Fund; remainder to General Fund to later be distributed to local governments. The established Marijuana Cash Fund will be used to pay for enforcement of rules and regulations.
Yes, continuing in existence with new

Dedicated marijuana fund run by Washington State Liquor Control Board. $\$ 125$ thousand to Healthy Use Survey; $\$ 50$ thousand to social and health reports; $\$ 5$ thousand to the University of Washington for web-based marijuana education; \$1.5 million to State Liquor Control Board; remainder: $15 \%$ to drug treatment; $10 \%$ for drug education; $1 \%$ to state university research; $50 \%$ to Washington Health Plan; $5 \%$ to community health care; $0.3 \%$ to building bridges program; remainder to General Fund.

Administrative sanctions or fines for violations or noncompliance

Prevention and treatment

Monitoring and evaluation
Yes, tiered schedule that includes up to $\$ 100,000$ fines and suspension and/or revocation of license.

Yes, law mandates that state agency will establish educational materials regarding appropriate retail marijuana use and prevention of marijuana use by those under 21.

Yes, required by law for Department of Health to monitor health effects every two years, starting in 2015 .
Yes, tiered schedule that includes up to $\$ 2500$ fine and suspension and/or cancellation of license.

Yes, some taxes generated will go to treatment

Yes, required by law to independently by Washington State Institute for Public Policy to evaluate policies and impacts related to health, security, economic effects, etc., starting in 2015 until 2032.

\section{Uruguay}

Required and to be specified during the call for applications for production licenses.

\section{Permitted. Between 15 and 45} members can collectively grow up to 99 plants, proportional to the number of members, with the maximum annual allotment of $480 \mathrm{~g}$ of dried product per year per member.

Yes, regulations currently being prepared.

Not specified

Yes, fines of up to $\$ 63,000$, seizures, and suspension or withdrawal of license.

Yes, the national health and education systems required to promote treatment and prevention.

Yes, by a specialized independent unit to evaluate the impact of the policy year by year.

Comparison of the world's first three jurisdictions to legally regulate marijuana: Colorado, Washington and Uruguay. USA: Drug Policy Alliance; $2014 .{ }^{40}$ Prepared with the input of Adrián A. Gutiérrez of "Rueda Abadi Pereira Consultores", based on the framework provided by Bryce Pardo of the Inter-American Drug Abuse Control Commission.

animals reveal other possible sites of action for these compounds, both in the central nervous system and the periphery. ${ }^{26}$

Work is currently underway on the development of synthetic endocannabinoid analogues without the CB1 and CB2-activation side effects, which trigger a therapeutic effect or recreational effect. ${ }^{27}$

\section{Endocannabinoid system tonic activity}

Endocannabinoids can behave as reverse agonists; they act when, in physiological conditions, the cannabinoid receptor is active without being bound to its direct agonist; the moment the reverse agonist binds to that receptor, it inactivates it and thus hampers its 
function. This way, sometimes, and only with a certain type of receptors, they can produce increased sensitivity to pain and trigger nausea, for example. ${ }^{28}$ This tonic activity may be due to endocannabinoids constant release or to the fact that part of cannabinoid receptors are naturally in an activated state. Endocannabinoid levels have also been observed to be higher in areas of the brain associated with pain (periaqueductal grey). ${ }^{29}$

Tonic control of spasticity by the endocannabinoid system is lost, for example, in cases of relapsing chronic experimental autoimmune encephalomyelitis in mice, a classic experimentation model in multiple sclerosis. The number of cannabinoid receptors has also been shown to be increased in models of chronic neuralgia due to neuronal damage in mice, as well as in models of intestinal inflammation. The same has been shown in terms of appetite control and vomiting in the emetic circuits of the brain..$^{30}$

$\triangle 9$-THC is cannabis most pharmacologically active phytocannabinoid and has a psychotropic effect that generates addiction, both in its herbal form (marijuana or raw cannabis) and in the modality resin (hashish). THC was characterized in the 1960s (Gaoni and Mechoulam, 1964), which opened the door to scientific investigation on marijuana's biological and medical properties and served as the basis for the development of derivatives with therapeutic activity, where separating pharmacological from psychoactive properties was attempted.

THC pharmacological effects depend on activation, as direct agonists, of its specific receivers, both in humans and in laboratory animals, whereas its antagonists can block specific receptor activity (passive antagonism) or produce the opposite effect (active antagonism). ${ }^{31,32}$

\section{Medicinal use of cannabis and its derivatives}

In recent years, studies have been carried out on the usefulness of cannabis derivatives in several diseases. By means of controlled clinical trials, the role of these derivatives in spasticity has been investigated in multiple sclerosis and medullary lesions, chronic pain, essentially neuropathic, movement disorders (Gilles de Latourette, dystonia, levodopa-induced dyskinesia), asthma and glaucoma. ${ }^{33}$ With non-controlled clinical trials, their effect on Alzheimer's disease, its role in neuroprotection, singultus or intractable hiccups, epilepsy, alcohol and opioid dependence and inflammatory processes have been assessed. Most studies have been carried out with approved and marketed synthetic substances; however, in most cases, cannabis has shown evidence of lower biological strength. ${ }^{34}$

Chronic pain is the reason for cannabis medicinal use most commonly declared by patients. It accounts for $90 \%$ of medicinal cannabis authorizations in Europe and the United States. ${ }^{35}$ The use of cannabis can block nerve impulse transmission at different levels (peripheral neurons, spinal cord and brain). Cannabinoids have shown efficacy in some specific types of chronic pain, such as neuropathic pain associated with human immunodeficiency virus infection, spinal cord injuries, multiple sclerosis and pain of cancer origin; however, cannabinoids are not first-choice drugs in the treatment of chronic pain. They are considered third and fourth-line in the treatment of neuropathic pain. ${ }^{36}$

Neurological diseases, as well as psychiatric and oncological conditions, have justified cannabis acceptance for medicinal use in several countries around the world. Some cannabinoids have been approved; however, due to the lack of scientific evidence on safety or efficacy, others have not been approved. They can be topically administered, by using vaporizers or ingested as food or oil; the latter method is mainly used in children with epilepsy and other conditions. ${ }^{37}$

\section{Cannabinoid medicinal use}

With the evidence that has been published, different regulatory agencies of the world have approved drugs that act on cannabinoid receptors for human use. ${ }^{36}$

In 2005, a pharmacological mixture was approved in Canada, composed of THC and cannabidiol, for use in neuropathic pain in multiple sclerosis and, more recently, in pain caused by cancer.

On the other hand, dronabinol, a synthetic form of THC, was approved by the Food and Drug Administration in 1986 and, therefore, marketed in the United States for the treatment of nausea and vomiting caused by chemotherapy and anorexia-cachexia syndrome (extreme thinness and lack of appetite) associated with acquired immunodeficiency syndrome. In addition, it has also been used in the control of certain types of pain, since it enhances morphine derivatives analgesic effect. ${ }^{38}$

On July 31,2013 , with 50 votes in favor, 46 against and three absences, in Uruguay's Chamber of Deputies, the draft to legalize marijuana sale and 
Table 4. Examples of the association between endocannabinoid receptor localization, probable physiological function and potential effect of marijuana

\begin{tabular}{|c|c|c|}
\hline $\begin{array}{l}\text { Normal endocannabinoid } \\
\text { receptor location }\end{array}$ & $\begin{array}{l}\text { Endocannabinoid regulation of } \\
\text { normal physiological function }\end{array}$ & Potential effects of marijuana \\
\hline $\begin{array}{l}\text { Cerebral cortex, hippocampus, } \\
\text { limbic } \\
\text { system }\end{array}$ & $\begin{array}{l}\text { Judgment, cognition, memory, state of } \\
\text { alertness, mood and behavior, perception } \\
\text { of time/color/sound }\end{array}$ & $\begin{array}{l}\text { Impaired judgment, cognition, memory, alertness status, } \\
\text { mood and behavior swings, altered or distorted, deteriorated } \\
\text { perception of time/color/sound }\end{array}$ \\
\hline Basal ganglia, cerebellum & Coordination, movement & Loss of coordination \\
\hline Hypothalamus & Appetite & Increased appetite \\
\hline Bone marrow & Nausea and vomiting & Nausea and vomiting reduction \\
\hline $\begin{array}{l}\text { Dorsal afferent spinal cord and } \\
\text { peripheral nociceptors }\end{array}$ & Pain perception & Reduced pain perception \\
\hline Visual system & Intraocular pressure & Intraocular pressure reduction \\
\hline Cardiovascular system & Heart rate, blood pressure & $\begin{array}{l}\text { Increased heart rate and blood pressure } \\
\text { in sitting or decubitus position }\end{array}$ \\
\hline Gastrointestinal system & Motility & Decreased intestinal motility \\
\hline Immune system & Immunity & Variable stimulation or suppression \\
\hline
\end{tabular}

self-cultivation was approved. On Tuesday, December 10, 2013, the Uruguayan Senate passed the 19/172 law, which was finally enacted by the executive branch on Tuesday, December 24, 2013, in Montevideo, Republic of Uruguay. ${ }^{39}$ Regulations in different places have their differences for possession, consumption, cultivation and marketing (Table 3). ${ }^{40}$

It should be emphasized that there is a clear difference between the use of cannabinoids as a therapeutic tool and the therapeutic use that has been wanted to give to marijuana, either smoked, ingested prepared with certain meals or topically applied. The differences are shown in Table $4 .{ }^{41}$

\section{Cannabinoids' clinical applications}

There are different forms of cannabis products that are available in some countries to be used for medical purposes, for example, in Canada; some of them are dronabinol (pill), nabilone (pill) and nabiximol (spray). ${ }^{42}$ Some pathological entities where there is more experience on cannabinoids medical use are described in Appendix $1,{ }^{43-60}$ which indicates the level of evidence these drugs have by pathological entity according to the Grade system (Appendix 2).

\section{Other therapeutic applications}

In addition to those previously commented, a significant number of possible therapeutic benefits of cannabis and its derivatives is currently under study. For example, CB1 receptors activation by the synthetic cannabinoid compound WIN 55212-2 has been shown to produce an interesting antitussive effect. On the other hand, cannabis administered as an aerosol would produce a significant bronchodilator effect for asthmatic patients; this route of administration would avoid the detrimental effects to the lungs caused by smoked cannabis. In contrast, cannabinoid CB1 receptor block is being investigated as a possible strategy in obesity prevention and in the treatment of addiction to various drugs of abuse (tobacco, cocaine, heroin, etc.). ${ }^{60}$

\section{Conclusions}

Current knowledge suggests that cannabinoids appear to be a new alternative to combat pain and other symptoms that fail to respond or partially respond to classical drug treatment. There is a need for more studies to be carried out in order to demonstrate the efficacy of this pharmacological group and thus integrate it into daily clinical practice, since, to this moment, there are few primary indications for its prescription due to the scarcity of available evidence. The scope of cannabinoid drugs appears to range from palliative use to therapeutic purposes. New lines of research point to a likely anti-tumor effect, which would open an alternative for cancer treatment; however, further evidence is needed in this field. Thus, 
cannabinoids seem promising in a wide range of pathological entities, but there is still a long way to go for their acceptance and use in routine clinical practice.

Approval of Cannabis sativa derivatives for therapeutic purposes in Mexico requires informing the health group, as well as the population, on what cannabinoids are and the therapeutic agents that can be used. The National Academy of Medicine of Mexico issued a position document for the use of Cannabis sativa derivatives for therapeutic purposes, where ailments feasible to receive this type of treatment and the actions that have to be deployed to carry out a healthy and regulatory management of these compounds are defined. It is necessary for the generation of scientific evidence of the benefit or impact deriving from the use cannabinoid-based drugs to be promoted in our country.

\section{References}

1. García-Robles J. Antología del vicio. Aventuras y desventuras de la mariguana en México. México: Laberinto; 2016.

2. United Nations Office on Drugs and Crime. 2015 Global estimates of drug use. Suiza: United Nations Office on Drugs and Crime; 2018.

3. Organisation for Economic Co-operation and Development. Data for Chart CO4.3.B. Cannabis use at age 15 by gender, 2013/14. Francia: Organisation for Economic Co-operation and Development; 2019.

4. Encuesta Nacional de Consumo de Drogas, Alcohol y Tabaco 20162017. México: Instituto Nacional de Psiquiatría Ramón de la Fuente Muñíz/Instituto Nacional de Salud Pública/Comisión Nacional Contra las Adicciones/Secretaría de Salud; 2017.

5. Villatoro-Velázquez JA, Bustos-Gamiño MN, Fregoso-Ito DA, Fleiz-Bautista C, Gutiérrez-López M, Amador-Buenabad N, et al. Contextual factors associated with marijuana use in school population. Salud Mental. 2017:40:93-101.

6. Campbell JM, Thompson R. A dictionary of Assyrian botany. Inglaterra: British Academy; 2014.

7. Elsohly MA, Slade D. Chemical constituents of marijuana: the complex mixture of natural cannabinoids. Life Sci. 2005:78:539-548.

8. Camp WH. The antiquity of hemp as an economic plant. J NY Bot Gard. 2014:110-113.

9. Di Marzo V. A brief history of cannabinoid and endocannabinoid pharmacology as inspired by the work of British scientists. Trends Pharmacol Sci. 2006;27:134-140.

10. Chopra IC, Chopra RN. The use of cannabis drugs in India. Bull Narc. 2013:9:4-29.

11. Durant WJ, Durant A. The story of civilization. Vol I. EE. UU.: Simon and Schuster; 2015

12. Thompson R. A study of American grown cannabis in comparison with various other sources. Am J Pharm. 2006:84:88-95.

13. Rawlinson G. The Persian wars. EE. UU.: Modern Library; 2015

14. European Monitoring Centre for Drugs and Drug Addiction. The state of the drugs problem in Europe. Luxemburgo: European Monitoring Centre for Drugs and Drug Addiction; 2011.

15. Decreto por el que se reforman y adicionan diversas disposiciones de la Ley General de Salud y del Código Penal Federal. México: Diario Oficial de la Federación; 2017.

16. Rodríguez-Carranza R. Los productos de cannabis sativa: situación actual y perspectivas en medicina. Salud Mental. 2012;35:247-256.

17. Ware M, Desroches J. Cannabis medicinal y dolor. Pain Clin Update. 2014;22:1-7

18. Madras BK. Update of cannabis and its medical use. En: Thirty-seventh meeting of the Expert Committee on Drug Dependence. Suiza: World Health Organization; 2015

19. Brenneisen, R. Chemistry and analysis of phytocannabinoids and other cannabis constituent. En: ElSohly, Mahmoud A editores. Marijuana and the cannabinoids. EE. UU.: Humana Press Inc.; 2007.

20. Rodríguez-Carranza R. Los productos de cannabis sativa: situación actual y perspectivas en medicina. Salud Mental. 2012;35:247-256.
21. Hermanson DJ, Marnett LJ. Cannabinoids, endocannabinoids, and cancer. Cancer Metastasis Rev. 2011;30:599-612.

22. Narváez GO, Guerrero CA. Bases moleculares de la inmunotoxicología experimental de la marihuana. Rev Fac Med Univ Nac Colombia. 2006:54:290-300.

23. Grotenhermen F. Los cannabinoides y el sistema endocannabinoide. Cannabinoids. 2006;1:10-14

24. Pertwee R. Receptors and pharmacodynamics: natural and synthetic cannabionoids and endocannabinoids. En: Guy GW, Whittle B, Robson P, editores. The medicinal uses of cannabis and cannabinoids. Inglaterra: Pharmaceutical Press; 2004.

25. Gómez-Del Pulgar T, Velasco G, Sánchez C, Haro A, Guzmán M. De novo-synthesized ceramide is involved in cannabinoid-induced apoptosis. Biochem J. 2002;363:183-188.

26. Carracedo A, Geelen MJH, Diez M, Hanada K, Guzmán M, Velasco G. Ceramide sensitizes astrocytesto oxidative stress: role of cannabinoids. Biochem J. 2004;380:435-440.

27. McAllister SD, Rigel TC, Horowitz MP, García A, Desprez PY. Cannabidiol as a novel inhibitor gene expression in gressive breast cancer cells. Mol Cancer Ther. 2007;6:2921-2927.

28. Price MR, Baillie GL, Thomas A, Stevenson LA, Easson M, Goodwin R, et al. Allosteric modulation of the cannabinoid CB1 receptor. Mol Pharmacol. 2005;68:1484-1495.

29. Massi P, Vaccani A, Ceruti S, Colombo A, Abbracchio MP, Parolaro D. Effects of cannabidiol, a nonpsychoactive cannabinoid. J Pharmacol Exp Ther. 2004:308:838-845.

30. Lambert DM, Fowler CJ. The endocannabinoid system: drug targets, and potential therapeutic applications. J Med Chem. 2005;48:5059-5087.

31. De la Fuente JR. Botánica, química y farmacología de cannabis sativa. En: Marihuana y salud. Facultad de Ciencias Económicas, Universidad Nacional Autónoma de México, Facultad de Medicina/Academia Nacional de Medicina; 2015.

32. Tamosiunas G, Pagano E, Artagaveytia P. Una introducción al perfil farmacológico y terapéutico de la marihuana. Arch Med Int. 2013;35:113-116.

33. Ramos-Atance JA, Fernández-Ruiz J. Uso de los cannabinoides a través de la historia. España: Departamento de Bioquímica/Facultad de Medicina/Universidad Complutense de Madrid; 2015

34. Araos P, Calado M. Adicción a cannabis: bases neurobiológicas y consecuencias médicas. Rev Esp Drogodependencias. 2014;39:9-29.

35. Lijarcio Jl. El consumo de sustancias en la conducción de vehículos, reflexiones y aproximaciones. Rev Esp Drogodependencias. 2015;40:5-11.

36. Whiting PF, Wolff RF, Deshpande S, Di-Nisio M, Duffy S, Hernández AV Cannabinoids for medical use: a systematic review and meta-analysis. JAMA. 2015;313:2456-2473

37. Regulación y perspectivas en América Latina sobre el uso del cannabis con fines medicinales. Regulación y perspectivas en América Latina sobre el uso del cannabis con fines medicinales. [Tesis de licenciatura]. Colombia: Universidad Católica de Colombia; 2017.

38. Narang S, Gibson D, Wasan AD, Ross EL, Michna E, Nedeljkovic SS, et al. Efficacy of dronabinol as an adjuvant treatment for chronic pain patients on opioid therapy. J Pain. 2008;9:254-264.

39. Ley Federal de Uruguay Capítulo 1 Cannabis psicoactivo de uso médico y no médico, artículo 3ํㅡㄹ del Decreto Ley 14.294, artículo 5ํㅡㄹ de la Ley No.19.172. Uruguay: Cámara de Representantes de la República Oriental del Uruguay.

40. A comparison of the world's first three jurisdictions to legally regulate marijuana: Colorado, Washington and Uruguay. EE. UU.: Drug Policy Alliance; 2014.

41. Schrot RJ, Hubbard JR. Cannabinoids: medical implications. Ann Med. 2016;48:128-141.

42. Kalant $\mathrm{H}$, Porat-Waller AJ. Clearing the smoke on cannabis. Medical use of cannabis and cannabinoids. An Update. Canadá: Canadian Centre on Substance Abuse; 2016.

43. Devinsky O, Marsh E, Friedman D, Thiele E, Laux L, Sullivan J. Cannabidiol in patients with treatment-resistant epilepsy: an open-label interventional trial. Lancet Neurol. 2016;15(3): 270-278.

44. Kalkach-Aparicio M, Cuéllar-Herrera M, Flores-Ramírez EL, Ruiz-Gadea P, Medina-Osti L, Trejo-Martínez D, et al. The use of cannabis as an antiepileptic treatment in Mexico: A review, bioethical analysis, discussion and position of the Hospital General de México Epilepsy Clinic. Rev Med Hosp Gen Mex. 2016;79:68-78.

45. Detyniechi K, Hirsch L. Marijuana use in epilepsy: the myth and the reality. Curr Neurol Neurosci Rep. 2015;15:65

46. Wade DT, Makela P, Robson P, House H, Bateman C. Do cannabis-based medicinal extracts have general or specific effects on symptoms in multiple sclerosis? A double-blind, randomized, placebo-controlled study on 160 patients. Mult Scler. 2004;10:434-441.

47. Rog DJ, Nurmikko TJ, Friede T. Randomized controlled trial of cannabis-based medicinal extracts in the treatment of neuropatic, pain due to multiple sclerosis. Ectrims. 2003;9:S25.

48. García-Caldentey J. Neuroprotección por cannabinoides en la enfermedad de Huntington: ensayo clínico Fase II, aleatorizado, doble ciego controlado con placebo y cruzado neuroprotección por cannabinoides en la enfermedad de Huntington [Tesis de doctorado]. España: Universidad de Alcalá; 2013. 
49. Fitz Charles MA1, Clauw DJ, Ste-Marie PA, Shir Y. The dilemma of medical marijuana use by rheumatology patients. Arthritis Care Res (Hoboken). 2014;66:797-801.

50. Baron EP. Comprehensive review of medicinal marijuana, cannabinoids, and therapeutic implications in medicine and headache: what a long strange trip it's been... Headache. 2015;55:885-916.

51. Fine PG, Rosenfeld MJ. The endocannabinoid system, cannabinoids, and pain. Rambam Maimonides Med J. 2013;4:e0022.

52. Yunkun D, Lei L, Yuhuai H, Kaiyun F, Jin L. Clinical practice guidelines for management of neuropathic pain. African Med J. 2012;102:312-325

53. Phillips TJ, Cherry CL, Cox S, Marshall SJ, Rice AS. Pharmacological treatment of painful HIV-associated sensory neuropathy: a systematic review and meta-analysis of randomised controlled trials. PLoS One. 2010;5:e14433.

54. Abel EL. Effects of marihuana on the solution of anagrams, memory and appetite. Nature. 1971:231:260-261.

55. Machado-Rocha FC, Stéfano SC, De-Cássia-Haiek R, Rosa-Oliveira LM, Da Silveira DX. Therapeutic use of cannabis sativa on chemotherapy-induced nausea and vomiting among cancer patients: systematic review and meta-analysis. Eur J Cancer Care (Engl). 2008;17:431-443.
56. Ste-Marie PA, Fitzcharles MA, Gamsa A, Ware MA, Shir Y. Association cannabis negative psychosocial parameters in patients with fibromyalgia. Arthritis Care Res (Hoboken). 2012;64:1202-1208.

57. Blake DR, Robson P, Ho M, Jubb RW, McCabe CS. Preliminary assessment of the efficacy, tolerability and safety of a cannabis Medicine (Sativex) in the treatment of pain caused by rheumatoid arthritis. Rheumatology (Oxford). 2006;45:50-52.

58. Brunet L, Moodie EE, Rollet K, Cooper C, Walmsley S, Potter M, et al. Marijuana Smoking does not accelerate progression of liver disease in HIV-hepatitis C coinfection: a longitudinal cohort analysis. Clin Infect Dis. 2013;57:663-670.

59. Berman JS, Symonds C, Birch R. Efficacy of two cannabis based medicinal extracts for relief of central neuropathic Pain from brachial plexus avulsion: results of a randomised controlled trial. Pain. 2004; 112:299-306

60. Collado K. Cuestiones de interés en torno a los usos terapéuticos del cannabis. España: Departamento de Farmacología/Centro de Investigación Biomédica en Red de Salud Mental; 2012.

Appendix 1. Table of evidences and therapeutic uses of cannabinoids

\begin{tabular}{|c|c|c|c|}
\hline Researcher & Cannabinoid & Clinical application & Level of evidence \\
\hline David J. Rog & Nabiximols & Multiple sclerosis & $2 \mathrm{~A}$ \\
\hline Garcia de Yébenes & Nabilone & Huntington's disease & 4 \\
\hline Detyniechi K. & Cannabidiol & Epilepsy & 4 \\
\hline Fitz Charles & Nabilone & Back pain & $2 \mathrm{~B}$ \\
\hline Wallace & Nabilone & Headache & $2 \mathrm{~B}$ \\
\hline Jonathan S. Berman & Nabilone & Peripheral neuropathic pain & $2 \mathrm{~B}$ \\
\hline Jonathan S. Berman & Nabilone/Nabiximols & Central neuropathic pain & $2 \mathrm{~B}$ \\
\hline Lynch M.Y. Campbell & Smoked cannabis & HIV-associated neuropathy & $2 \mathrm{~B}$ \\
\hline Whiting P.F., Wolff R.F. & Dronabinol & HIV-associated anorexia & 3B \\
\hline Ste-Marie & Nabilone & Fibromyalgia & $2 \mathrm{~B}$ \\
\hline George W. & Nabiximols & Rheumatoid arthritis & $2 \mathrm{~B}$ \\
\hline Brunet L. & Cannabidiol & Hepatitis C & 4 \\
\hline Whiting P.F., Wolff R.F. & Dronabinol & Post-chemotherapy nausea and vomiting & $2 \mathrm{~B}$ \\
\hline Whiting P.F., Wolff R.F. & Cannabidiol & Glaucoma & $2 \mathrm{~B}$ \\
\hline Whiting P.F., Wolff R.F. & Cannabidiol & Depression/Anxiety & $2 \mathrm{~B}$ \\
\hline
\end{tabular}

Whiting PF, Wolff RF, Deshpande S, Di-Nisio M, Duffy S, Hernández AV. Cannabinoids for medical use: a systematic review and meta-analysis. JAMA. 2015; 313:2456-2473. ${ }^{36}$ 
Gaceta Médica de México. 2019;155

Appendix 2. GRADE system, quality of evidence classification and strength of recommendation grading ${ }^{45}$

\begin{tabular}{|l|l|l|}
\hline $\begin{array}{l}\text { Degree of } \\
\text { recommendation }\end{array}$ & $\begin{array}{l}\text { Level of evidence } \\
\text { A }\end{array}$ & Type of study \\
\hline A & Systematic review (with homogeneity) of controlled clinical trials. \\
\hline B & Controlled clinical trials (with narrow confidence interval). \\
\hline & 2A & Systematic review (with homogeneity) of cohort studies. \\
\hline & In & Individual cohort study/individual low quality RCT*. \\
\hline C & Systematic review (with homogeneity) of case-control studies. \\
\hline D & Individual case-control study. \\
\hline
\end{tabular}

Sackett DL, Haynes RB, Guyatt GH, Tugwell P. Epidemiología Clínica. Ciencia básica para la medicina clínica. 2nd edition. Madrid: Editorial Medica Panamericana; 1994. ${ }^{*} \mathrm{RCT}$ : randomized controlled trial. 